\title{
Pelaksanaan Program Pembangunan Modal Insan (PMI) di institusi Pengurusan Hal Ehwal Islam (PHEI): Kajian Kes di Jabatan Kemajuan Islam Malaysia (JAKIM)
}

\author{
Implementation of Human Capital Development Program at the Institutions of Islamic Affairs Management: \\ A Case Study at Department of Islamic Development Malaysia (JAKIM) \\ Sa'adi Awanga, ${ }^{*}$, Siti Arni Basirb ${ }^{b}$, Hasan Al-Banna Mohamedc \\ aBabagian Pendidikan, Jabatan Kemajuan Islam Malaysia (J AKIM), Aras 5, Blok B, Kompleks Islam Putrajaya, No. 23, \\ Jalan Tunku Abdul Rabman, Presint 3, 62100 Putrajaya \\ babatan Siasah Syar'iyyah, Akademi Pengajian Islam, Universiti Malaya, Kuala Lumpur \\ cPusat Jaminan Kualiti dan Pengurusan Data, Universiti Pertahanan Nasional Malaysia, Kem Sungai Besi \\ *Corresponding author: saadi@islam.gov.my
}

\section{Article history}

Received: 2018-05-30 Received in revised form: 2019-08-15 Accepted: 2019-08-16 Published online: 2019-10-31

\begin{abstract}
Human capital is an important asset for the survival of organization. Poor human capital are not able to contribute effectively to the development of organization. Therefore, human capital must be developed through appropriate programs so that their potential can be harnessed to maximum level. Institutions of Islamic Affairs Management plays an important role in Malaysia. These institutions need competent human capital to ensure quality of services delivered are in accordance with customer expectations. However, human capital competency in the institutions of Islamic Affairs Management is still questionable. Literature shows that empirical studies about human capital development programs in the institutions of Islamic Affairs Management is sorely lacking. Therefore, the objective of this study is to explore the implementation of human capital development programs in the institution of JAKIM. This study employed qualitative methods using the JAKIM as case study organisation. A total of 15 informants were interviewed in this study. Data were analysed using thematic analysis which is facilitated by ATLAS ti software. The results showed there are 5 human capital development programs implemented in JAKIM that is training, education and knowledge, human resource management, quality and work experiences. The results also shows all the programs have been well implemented. The administrators either in public or private sector can use these findings as a guide to implement human capital development programs in their organisations effectively.
\end{abstract}

Keywords: Human capital development, program, institutions of Islamic Affairs Management, JAKIM, case study

\begin{abstract}
Abstrak
Modal insan merupakan aset penting bagi kelangsungan organisasi. Modal insan yang lemah tidak mampu menyumbang secara efektif kepada organisasi. Oleh itu, modal insan perlu dibangunkan melalui program-program bersesuaian agar potensi mereka dapat dikembangkan ke tahap maksimum. Institusi Pengurusan Hal Ehwal Islam (PHEI) memainkan peranan penting di Malaysia. Institusi tersebut memerlukan modal insan yang cekap untuk memastikan kualiti perkhidmatan yang disediakan mampu memenuhi kehendak pelanggan. Namun begitu, kecekapan modal insan di institusi PHEI masih menjadi isu. Literatur menunjukkan kajian empirikal mengenai program pembangunan modal insan di institusi PHEI masih begitu kurang dijalankan. Oleh itu, objektif kajian ini adalah untuk meneroka perlaksanaan program pembangunan modal insan yang dilaksanakan di JAKIM. Kajian ini menggunakan kaedah kualitatif dengan menggunakan JAKIM sebagai kajian kes. Seramai 15 orang informan
\end{abstract}


telah ditemu bual dalam kajian ini. Data telah dianalisis menggunakan kaedah analisis tema dengan bantuan perisian ATLAS ti. Hasil kajian menunjukkan terdapat 5 program pembangunan insan yang dilaksanakan di JAKIM iaitu latihan, pendidikan dan ilmu pengetahuan, pengurusan sumber manusia, kualiti dan pengalaman kerja. Hasil kajian juga menunjukkan semua program tersebut telah dilaksanakan dengan baik. Para pentadbir sama ada di sektor awam atau swasta boleh menggunakan hasil kajian ini sebagai panduan untuk melaksanakan program pembangunan modal insan di organisasi masing-masing secara berkesan.

Kata kunci: Pembangunan modal insan, program, Pengurusan Hal Ehwal Islam (PHEI), JAKIM, kajian kes.

\subsection{PENGENALAN MODAL INSAN (MI) DAN PEMBANGUNAN MODAL INSAN (PMI)}

Teori asas modal insan telah diasaskan oleh Schultz (1961) di mana beliau mengatakan modal insan termasuklah pendidikan, latihan, penghijrahan dan kesihatan pekerja. Teori ini telah dikembangkan dan dimajukan semula oleh Becker (1962) yang membuat kajian modal insan dalam organisasi terutamanya dalam bidang ekonomi buruh. Teori yang dikemukakan oleh Becker menunjukkan hubungan positif antara upah yang diterima oleh buruh dengan tingkat pendidikan. Kajian oleh Becker ini telah disahkan lagi oleh kajian Michel (2015) yang mendapati kepentingan pelaburan modal insan dan pulangannya kepada organisasi. Manakala Unger et al. (2011) pula berpandangan konsep modal insan hanya merujuk kepada pekerja dalam organisasi di mana setiap pekerja akan diberi ganjaran berdasarkan kepada pekerjaan mereka. Ployhart dan Moliterno (2011) pula menyatakan konsep modal insan dalam bidang keusahawanan merujuk hubungan antara modal insan dan kejayaan mereka dalam perniagaan. Kejayaan ini merujuk kepada pelbagai aspek antaranya pengalaman, kepintaran, bidang perniagaan yang diceburi dan sebagainya.

Teori oleh Schultz dan Becker iaitu terdapat hubungan yang positif antara pencapaian modal insan seseorang dengan tingkat pendapatan mereka telah diuji kesahihannya oleh banyak pengkaji. Antaranya ialah Biswajit (2016), Unger et al. (2011), Kwon (2009), Daeboug (2009). Kajian mereka menunjukkan terdapat hubungan yang signifikan apabila pencapaian modal insan dalam pendidikan diberikan hak yang sama antara rakyat sesebuah negara, maka agihan pendapatan dalam masyarakat akan bertambah baik dan adil.

Umumnya teori modal insan menyatakan bahawa pendidikan, latihan, sikap, tingkah laku, kemahiran dan pembangunan kerjaya serta lain-lain pengetahuan mempunyai kesan positif ke atas nilai produktiviti dan upah serta dapat melonjakkan prestasi diri dalam kehidupannya seperti kajian oleh Becker dan Huselid (2006), Colbert (2004) serta kajian Kaufman dan Miller (2011). Manakala kajian oleh Gjalt (2015) pula mendapati pendidikan dan latihan formal untuk pembelajaran atau on the job tranning and learning yang disediakan oleh organisasi juga merupakan kaedah untuk membangunkan modal insan. Teori modal insan juga boleh digambarkan melalui penambahan faktor-faktor pengeluaran dan pulangan yang akan diperoleh organisasi hasil daripada pelaburan modal insan.

Pembangunan Modal Insan (PMI) pula merupakan sebahagian daripada konsep pembangunan insan atau pembangunan manusia. Ianya merupakan konsep yang telah diterima pakai oleh Pertubuhan Bangsa-Bangsa Bersatu pada tahun 1990. Menurut Les (2005) PMI adalah termasuk amalan kepimpinan, penglibatan pekerja dalam organisasi, akses pengetahuan, memaksimumkan tenaga kerja

Page 10 
dan keupayaan dalam pembelajaran. Khalique et al. (2015) pula menjelaskan PMI sebenarnya merangkumi kecekapan, sikap, kepimpinan dan ilmu pengetahuan. Manakala Enrique et al. (2015) pula menyatakan komponen modal insan terdiri daripada bukan sahaja pengetahuan, kemahiran dan keupayaan yang dimiliki dan digunakan oleh individu, malahan ianya juga merangkumi semua keupayaan mereka dalam menggunakan sumber-sumber pengeluaran.

Venhorst et al. (2010) menyatakan modal insan yang berkualiti, profesional, berpendidikan dan berprestasi tinggi merupakan kunci kepada pertumbuhan ekonomi negara. Mereka bukan sahaja merupakan aset negara yang penting tetapi menjadi tenaga penggerak kepada pencapaian wawasan 2020 yang akan meletakkan Malaysia sebagai sebuah negara maju dan mempunyai daya saing di peringkat global. Pekerja atau modal insan adalah salah satu aset penting dalam membangunkan dan memajukan sesebuah organisasi. Oleh itu, perhatian yang tinggi terhadap penghasilan modal insan adalah amat penting dan perlu dijana dan dilatih secara berterusan agar modal insan ini dapat membantu dalam merealisasikan setiap visi dan misi yang telah diletakkan.

Pendidikan dan latihan merupakan aspek utama dalam pembangunan modal insan. Aspek ini penting kerana pendidikan dan latihan dapat meningkatkan produktiviti pekerja di mana pengetahuan dan kemahiran yang dimilikki oleh seseorang individu dapat meningkatkan produktiviti modal insan. Kebanyakan penyelidik berkaitan bidang organisasi mula melihat kepentingan pembangunan modal insan dalam usaha meningkatkan keuntungan organisasi. Kajian oleh Siti Nur Aisya dan Ahmad Zabidi (2016), Siti Arni et. Al (2016), Enrique et al. (2015), Trudi (2013), Biswajit (2016), Adedeji dan Campell (2017), Guangqiang et. Al (2017) dan Abdifatah (2016) menunjukkan pendidikan dan latihan membawa impak positif kepada pembangunan modal insan seterusnya membantu dalam meningkatkan prestasi organisasi.

Kajian Rahmah et al. (2011) menyatakan penglibatan pekerja merupakan aspek penting dalam pembangunan sesebuah organisasi. Organisasi yang berjaya adalah organisasi yang menguruskan secara proaktif para pekerjanya dan mewujudkan persekitaran kerja yang kondusif dan selamat. Bagi memastikan semua ini berlaku organisasi harus memastikan masa pekerja digunakan dengan baik dan adil, mengiktiraf dan menghargai pekerja dan kerja mereka serta menyediakan peluang untuk kemajuan kerjaya. Ianya penting dalam memastikan objektif organisasi tercapai. Manakala kajian Juan et al. (2015) pula mendapati apabila pengurusan sumber manusia sesuatu organisasi berada adalah dalam keadaan baik dan cekap, ianya akan membawa kepada peningkatan produktiviti dan pelbagai faedah diperoleh organisasi. Ini menunjukkan pentingnya pembangunan modal insan diuruskan dengan baik untuk kelangsungan organisasi.

Hasil kajian oleh Siti Fatimah et al. (2016) pula mendapati mendapati kelemahan mengurus risiko dalam pembangunan sumber manusia atau modal insan merupakan antara punca utama kegagalan pengurusan sumber manusia di sektor awam Malaysia. Kegagalan mengenal pasti risiko semasa fasa perancangan pembangunan modal insan boleh meningkatkan kos dan tempoh masa untuk menanganinya. Oleh yang demikian dalam membuat perancangan program pembangunan modal insan, penting bagi pengurusan sumber manusia mengenal pasti risiko-risiko yang akan dihadapi semasa membangunkan program-program pembangunan modal insan dalam organisasi.

Manakala Kajian Christopher dan Adeleke (2016), Samson dan Timothy (2014), Rahmah et al. (2011) dan Augusto et al. (2014) kesemuanya berkaitan dengan aspek kualiti pembangunan modal

Page | 11 
insan yang menunjukkan modal insan yang mempunyai kualiti secara asasnya dapat meningkatkan kemajuan organisasi.

Malaysia tidak terkecuali menjadikan PMI sebagai salah satu strategi bagi membangunkan negara di persada antarabangsa. Berdasarkan teras dasar yang telah digariskan oleh kerajaan, modal insan yang ingin dibangunkan adalah individu yang berilmu, berkeyakinan, mempunyai nilai murni dan moral yang tinggi, beretika, berbudi bahasa, inovatif, kreatif, bersemangat patriotik, berdaya saing dan memiliki personaliti unggul bagi menentukan hala tuju negara pada masa hadapan (Prime Minister Office, 2013).

\subsection{MODAL INSAN DI INSTITUSI PENGURUSAN HAL EHWAL ISLAM (PHEI)}

Institusi Pengurusan Hal Ehwal Islam (PHEI) hampir menyamai sebuah Kementerian Agama Islam di Malaysia yang diketuai oleh seorang Menteri berportfolio Agama di Jabatan Perdana Menteri (JPM). Institusi ini mengepalai agensi-agensi Islam di peringkat persekutuan seperti Jabatan Kehakiman Syariah Malaysia (JKSM), Jabatan Agama Islam Wilayah Persekutuan (JAWI) dan Tabung Haji. Manakala Majlis Agama Islam Negeri-negeri (MAIN), Jabatan Mufti Negeri-negeri dan Jabatan Agama Islam Negeri-negeri (JAIN) mempunyai hubungan secara langsung dengan Menteri berportfolio Agama di Jabatan Perdana Menteri (JPM) (Pelan Strategik JAKIM 2014). Antara Institusi Pengurusan Hal Ehwal Islam (PHEI) di Malaysia ialah Jabatan Kemajuan Islam Malaysia (JAKIM).

JAKIM merupakan Institusi Pengurusan Hal Ehwal Islam (PHEI) di peringkat pusat yang memainkan peranan penting berhubung dengan kehidupan masyarakat Islam di Malaysia. Walaubagaimanapun, terdapat dakwaan menyatakan bahawa pegawai-pegawai JAKIM kurang pengetahuan dan kecekapan dalam menangani isu-isu dan hal ehwal umat Islam kerana mereka kurang bergaul dengan masyarakat. Ada pegawai yang telah dihantar ke agensi peringkat negeri namun mereka tiada inisiatif dan motivasi untuk bekerjasama dengan Majlis Agama Islam Negeri dalam menangani sesuatu isu berhubung umat Islam. Selain itu, para pegawai tersebut kurang pendedahan, lemah dari segi penguatkuasaan undang-undang dan pentadbiran kariah masjid. Bagi mengatasi masalah ini, perubahan perlu dilakukan dengan memberi pendedahan dan kemahiran baru kepada pegawai JAKIM. Selain itu, JAKIM juga perlu merangka program baru yang menepati kehendak semasa dan mengarahkan kakitangannya sentiasa turun padang bagi mengukuhkan akidah umat Islam (Utusan Malaysia, 2014).

Selain itu, terdapat juga pegawai di institusi PHEI yang dikaitkan dengan perbuatan salah laku. Maka tidak hairanlah JAKIM telah melancarkan Sistem Penarafan Penguatkuasaan dan Pendakwaan (SPPP) Syariah Jabatan Agama Islam Negeri (JAIN) seluruh Malaysia. Matlamat SPPP adalah membantu JAKIM untuk menyelaras pelaksanaan tindakan penguatkuasaan dan pendakwaan Syariah di samping membantu negeri-negeri menilai kekuatan dan kelemahan mengikut penanda aras yang ada seterusnya berusaha memperbaiki dan meningkatkan potensi modal insan dan pembangunan organisasi setanding dengan agensi penguatkuasaan lain di negara ini (Laman Web JAKIM, 2018).

Dapatan awal temubual bersama informan dalam kajian ini mendapati bahawa para pegawai di JAKIM berhadapan dengan beberapa isu tertentu seperti kekurangan latihan jangka pendek dan jangka panjang. Selain itu, peluang untuk melanjutkan pengajian ke peringkat tinggi seperti peringkat sarjana

Page $\mid 12$ 
dan doktor falsafah juga terhad. Ini menyebabkan modal insan di JAKIM kurang mendapat latihan dan pendedahan, seterusnya menjadikan mereka agak lemah dari sudut tertentu seperti lemah di segi pentadbiran, pelaksanaan operasi gerak kerja dan komunikasi. Bukan itu sahaja, peluang pembangunan kerjaya dan kenaikan pangkat juga agak terhad di JAKIM kerana ianya mengamalkan skim perkhidmatan tertutup, iaitu kenaikan pangkat bukan berasaskan prestasi sepenuhnya, tetapi bergantung kepada kekosongan perjawatan yang ada. Peluang kenaikan pangkat yang terhad ini membataskan peluang pembangunan kerjaya seterusnya membataskan keupayaan modal insan di JAKIM untuk menyerlahkan potensi mereka ke tahap maksimum. Situasi ini secara langsung telah meninggalkan kesan negatif kepada matlamat pembangunan modal insan dalam usaha untuk melahirkan modal insan yang berkualiti dan cemerlang.

Walaupun banyak kajian mengenai PMI telah dilakukan seperti oleh Ballout (2007), Zula dan Chermack (2007), Philip (2010), Rahmah et al. (2011), Khadijah et al. (2013), Lai dan Ishak (2014), Zainudin et al. (2015), Fatimah dan Nor Hayati (2015) dan Muhammad Hilmi dan Fakhrul Adabi (2013), namun kajian modal insan di institusi Islam masih begitu kurang dilakukan. Begitu juga kajian mengenai JAKIM pada umumnya telah banyak kajian yang dilakukan, namun kajian-kajian tersebut tidak memfokuskan kepada isu PMI di JAKIM. Antara kajian yang pernah dilakukan oleh pengkaji ialah kajian Nor Azzah dan Nurul Izzah (2011), Abdullah (2011), Sedek (2012) dan Lokman (2012). Berdasarkan kajian pengkaji terdahulu, masih terdapat kelompangan literatur yang jelas tentang kajian empirikal mengenai PMI di JAKIM. Kebanyakan kajian terdahulu hanya memfokuskan berkaitan dengan pengurusan masjid, pengurusan halal dan pengurusan pusat tahfiz.

Perbincangan di atas menunjukkan institusi pengurusan hal ehwal Islam (PHEI) di Malaysia khususnya di peringkat pusat berhadapan dengan masalah berkaitan dengan modal insannya. Status dan kualiti modal insan di institusi tersebut mempengaruhi kualiti perkhidmatan yang diberikan. Kualiti perkhidmatan yang kurang memuaskan sedikit sebanyak telah menjejaskan kepercayaan orang ramai, pelanggan dan pihak berkepentingan. Oleh itu, institusi PHEI perlu mempunyai modal insan yang berkeupayaan tinggi dan cekap untuk menghasilkan perkhidmatan yang berkualiti. Namun begitu, modal insan di institusi PHEI masih berhadapan dengan masalah tertentu. Perbincangan di atas juga menunjukkan kajian empirikal mengenai PMI di JAKIM belum pernah dijalankan. Justeru itu, terdapat keperluan untuk mengkaji tentang perlaksanaan program pembangunan insan di institusi PHEI Malaysia. Objektif kajian ini adalah untuk meneroka perlaksanaan program pembangunan modal insan yang dilaksanakan di JAKIM. Kajian ini akan mengenalpasti program pembangunan modal insan yang dilaksanakan dan meneroka tentang bagaimana program-program tersebut dilaksanakan.

\subsection{LITERATUR PROGRAM PEMBANGUNAN MODAL INSAN (PMI)}

Bahagian ini membincangkan literatur 2 jenis program PMI iaitu latihan dan pendidikan dan ilmu pengetahuan.

\subsection{Program Latihan}

Pemberian latihan dalam organisasi dapat memastikan sesebuah organisasi bertahan lebih lama (Enrique et al. 2015). Selain itu, latihan juga mampu meningkatkan produktiviti organisasi (Mohamed et al., 2017). Bagi pihak pekerja, latihan semasa kerja dapat meningkatkan tahap kecekapan dan keterbukaan serta membekalkan mereka pengalaman bagi menjalankan tugas dengan sempurna dan

Page | 13 
seterusnya mencapai matlamat organisasi. Manakala bagi organisasi pula pengendalian latihan merupakan satu pelaburan jangka panjang untuk mencapai objektif atau matlamat organisasi yang bermotifkan keuntungan. Menerusi latihan juga berlakunya peningkatan keupayaan dan kemahiran pekerja yang membolehkan mereka menghasilkan produktiviti dan perkhidmatan terbaik kepada pelanggan (Philip, 2010). Sehubungan dengan itu, Kamal et al. (2017) menegaskan oleh kerana program latihan merupakan pelaburan jangka panjang untuk meningkatkan prestasi organisasi, maka ilmu atau pengetahuan yang penting dan kritikal perlu dimasukkan dalam program tersebut.

Kajian Kwame dan Irene (2016) mendapati latihan dan pengetahuan yang diterima semasa bekerja merupakan komponen penting dalam menentukan kejayaan modal insan dan organisasi. Sehubungan dengan itu, Wright (2013) menyatakan modal insan dalam organisasi yang menerima latihan secara formal menunjukkan kompetensi dalam perkhidmatan. Manakala Hong et al. (2007) mendapati individu di Amerika Syarikat yang tidak berpendidikan tinggi tetapi mendapat peluang meningkatkan kemahiran melalui latihan serta mempunyai status kesihatan baik mempunyai peluang yang rendah menjadi miskin. Ini menunjukkan latihan merupakan aspek penting dalam program PMI kerana ianya membawa kesan signifikan kepada kehidupan seseorang pekerja.

\subsection{Program Pendidikan Dan Ilmu Pengetahuan}

Kajian oleh Biswajit (2016) mendapati pelaburan dalam pendidikan merupakan asas kemajuan organisasi. Menurut Sylwester (2000), PMI meliputi aspek pendidikan merupakan instrumen penting dalam membangunkan modal insan dan ianya mampu mengurangkan jurang pendapatan terutamanya di antara pekerja mahir dan kurang mahir. Sehubungan dengan ini, kajian oleh Arabsheibani et al. (2014) di Brazil mendapati pencapaian dalam pendidikan bukan hanya dapat menerangkan realiti dalam bidang pekerjaan malah merupakan satu bentuk ganjaran yang mampu meningkatkan pulangan dan seterusnya mendorong pengagihan perolehan ekonomi yang lebih adil.

Pencapaian dalam pendidikan membantu pekerja mencapai kejayaan dalam kerjaya (Murwani \& Casear, 2016). Selain itu, memilikki pendidikan tinggi mempengaruhi pembuatan keputusan seperti kajian di China oleh Yao (2008) menunjukkan mereka yang berpendidikan dalam sesebuah organisasi berada dalam kedudukan tinggi dan berupaya untuk membuat keputusan serta dapat memajukan sesebuah organisasi.

Sebenarnya, pendidikan mempunyai kaitan rapat dengan pembelajaran. Rahmah et al. (2011) menyatakan bahawa keupayaan dalam pembelajaran merupakan keupayaan keseluruhan organisasi untuk belajar, berinovasi dan melaksanakan agenda penambahbaikan. Keupayaan dalam pembelajaran ini melibatkan aspek latihan, pembangunan dan inovasi. Perkara ini mesti disokong oleh organisasi agar modal insan mempunyai keupayaan untuk bertindak balas terhadap perubahan persekitaran dan konsisten dalam usaha mencapai matlamat organisasi.

\subsection{PEMBANGUNAN MODAL INSAN PERSPEKTIF ISLAM}

Islam melihat insan atau manusia dalam konteks keseluruhan dan kesempurnaan diri yang mana tanggungjawab utama insan diutus adalah untuk tunduk dan patuh kepada Allah. Oleh yang demikian modal insan dari perspektif Islam adalah satu keunggulan keperibadian yang dimiliki oleh manusia dalam konteks melaksanakan tugas dan tanggungjawab bersama yang telah diamanahkan bagi kemakmuran manusia dan alam ciptaan-Nya. Islam juga menekankan aspek kepentingan ilmu 
pengetahuan menerusi ayat pertama yang diturunkan oleh Allah Taala kepada Nabi Muhammad SAW iaitu surah al-Alaq (al-Quran 96: 1-5) yang memberi isyarat betapa Islam memberikan perhatian yang cukup besar tentang ilmu pengetahuan. Ilmu pengetahuan juga dapat mengukur darjat dan kedudukan manusia.

Insan merupakan aset yang perlu dibangunkan. Islam mendukung penuh usaha membentuk dan membangunkan insan berkualiti bahkan konsep kualiti itu sendiri adalah unik dalam Islam kerana ia merangkumkan kedua-dua aspek fizikal dan rohani, dunia dan akhirat (Zainudin et al., 2015 dan Muhammad Hilmi \& Fakhrul Adabi, 2013). Dalam Islam, pembangunan modal insan bersifat lebih holistik dengan menjadikan Allah SWT sebagai paksi segala tujuan sekaligus mengangkat martabat insan sebagai makhluk yang bermaruah (Muhamad Alihanafiah, 2011). Pembangunan modal insan yang berjaya direalisasikan melalui sirah Nabi SAW dalam membentuk ummah dan negara baru pada awal perkembangan Islam yang dimulai dengan revolusi ilmu. Melalui revolusi ini akhirnya telah berjaya membentuk reformasi dalam pendidikan yang memancangkan cara berfikir, tingkah laku, akhlak, hukum agama, undang-undang dan aturan hidup (Siti Fatimah dan Maimun Aqsha, 2015). Abdul Rahman (2006) pula menyatakan konsep modal insan menurut perspektif Islam ialah satu keunggulan peribadi yang dimiliki oleh manusia iaitu penguasaan ilmu pengetahuan, kemahiran yang tinggi dan akhlak yang mulia dalam melaksanakan tugas dan tanggungjawab bersama yang diamanahkan Allah Taala bagi meningkatkan kemakmuran manusia dan alam seluruhnya.

Manakala menurut Fauzi dan Khairul (2012) pula pembangunan modal insan dari perspektif Islam adalah pembangunan yang melihat insan sebagai watak terpenting dalam sesebuah pembangunan. Ianya dibangunkan dari dalam dan luar diri manusia di mana ianya bergerak bersama dengan pembangunan dan tidak boleh diasingkan dengan rangka kerja yang lain. Hal ini berlaku kerana pembangunan Islam ialah pembangunan yang bersepadu dan menyeluruh meliputi rohani dan jasmani serta dunia dan akhirat. Dalam Islam tiada istilah insan selaku modal yang memberi keuntungan material kerana material hanya satu bahagian dari matlamat yang ingin dicapai. Tetapi kadar pulangan yang dihajati adalah ganjaran di dunia dan juga di akhirat berdasarkan amal soleh dan kerja kuat yang dilaksanakan dalam amalan hidup seharian.

Terdapat kajian yang memfokuskan pembangunan modal insan pada zaman Rasulullah (SAW). Umpamanya Adnan dan Nor 'Azzah (2013) memfokuskan kepada pendekatan pembangunan modal insan yang digunakan pada zaman Rasulullah s.a.w. Kajian mereka mendapati pembangunan modal insan pada era ini merangkumi pembangunan yang bersepadu dan menyeluruh meliputi rohani dan jasmani serta dunia dan akhirat. mereka juga menumpukan kajian pembangunan modal insan dalam organisasi yang di bangunkan pada era Rasulullah.

Konsep modal insan dari perspektif Islam dan Barat amat berbeza terutama dalam mencapai objektif dan matlamat pembangunan modal insan. Menurut Ab. Aziz (2015) konsep pembangunan modal insan dari perspektif Barat hanya bergantung kepada kekuatan pemikiran manusia yang dipercayai akan mempengaruhi prestasi kerja. Manakala Islam kekuatan pemikiran manusia adalah terbatas dan sering terdedah kepada pelbagai kelemahan sehingga memerlukan bimbingan agama. Mutasim et al. (2014) pula telah melakukan kajian mengenai kecekapan pengurusan organisasi. Mutasim et al. (2014) juga telah membuat perbandingan antara konsep kecekapan Barat dengan konsep kecekapan dalam Islam di mana mereka mendapati perbezaan utama antara model kecekapan Barat

Page $\mid 15$ 
dan model Islam terletak pada sumber rujukan, falsafah dan prinsip-prinsip. Sumber rujukan, falsafah dan prinsip-prinsip model kecekapan Barat terletak pada pengalaman dan pengetahuan pengkaji sendiri yang dibentuk melalui nilai pemikiran dan budaya mereka. Manakala model Islam berpegang teguh kepada prinsip-prinsip al-Quran dan Hadis. Sumber-sumber ini berfungsi sebagai asas bagi umat Islam, termasuk pengurus bagi mencapai matlamat duniawi tanpa memisahkan kehidupan di dunia akhirat.

Kegagalan modal insan yang diperkenalkan oleh Barat menyebabkan pembangunan modal insan dari perspektif Islam mula mengambil tempat. Mohd Kamal (2013) telah meletakkan satu kerangka konsep baru dalam pembangunan modal insan iaitu menurut konsep tauhid yang merangkumi aspek ketuhanan, kehidupan dan matlamat akhir kehidupan dan sebagainya dalam usaha menangani kegagalan pembangunan modal insan. Beliau membuat perbandingan modal insan dalam ekonomi terhadap beberapa organisasi besar dari seluruh dunia dan juga beberapa negara Islam. Walau bagaimanapun Islam juga bersetuju dengan teori modal insan Barat mengenai peningkatan pendidikan, kemahiran dan kebolehan. Namun melalui perspektif Islam teori ini lebih menyeluruh merangkumi setiap aspek pembangunan seorang manusia. Selain itu masyarakat Islam memainkan peranan penting bagi pembangunan modal insan. Faruk (2012) mendapati walaupun Islam bercakap tentang pembangunan kebolehan manusia dan kemahiran, tetapi Islam menekankan matlamat akhir penciptaan insan di bumi ini iaitu untuk beribadah kepada Allah.

\subsection{METODOLOGI}

Kajian kualitatif ini menggunakan kajian kes sebagai strategi kajian. JAKIM telah dipilih sebagai organisasi kajian kes. Kaedah pengumpulan data utama dalam kajian ini ialah dengan menggunakan kaedah temu bual separa-struktur. Selain itu, kajian ini juga menggunakan kaedah analisis dokumen terhadap dokumen-dokumen yang berkaitan dengan topik yang dikaji. Teknik temu bual digunakan memandangkan ia merupakan satu cara cepat bagi mendapatkan maklumat yang banyak dalam masa singkat (Cohen et al. 2013).

Pensampelan informan yang digunakan dalam kajian ini ialah pensampelan bertujuan. Sampel iaitu informan kajian telah dipilih berdasarkan tujuan utama kajian ini iaitu untuk mendapatkan input dan pandangan berkaitan PMI di JAKIM.

Dalam kajian ini, pengkaji telah memilih informan yang terdiri daripada mereka yang terlibat secara langsung dan aktif dengan perlaksanaan program modal insan di JAKIM. Pengkaji telah mengkategorikan informan yang mewakili pembuat dasar dan pelaksana program modal insan di JAKIM. Ini adalah memadai bagi mendapatkan input dan pengalaman sebenar mereka tentang perlaksanaan program PMI di JAKIM. Oleh yang demikian, pengkaji telah mengambil seramai lima belas orang informan iaitu empat orang pengurusan tertinggi dan sebelas orang pegawai serta kakitangan JAKIM. Pengkaji mengkategorikan informan kepada tiga kumpulan pengurusan JAKIM yang utama iaitu:

1. Seorang Pengurusan Tertinggi di JAKIM iaitu Timbalan Ketua Pengarah Pembangunan Insan JAKIM;

Page | 16 
2. Pengurusan tertinggi di peringkat bahagian iaitu Seorang Pengarah Bahagian Pengurusan Sumber Manusia dan dua orang Ketua Penolong Pengarah Kanan (KPPK) yang melaksanakan dasardasar berkaitan modal insan; dan

3. Sebelas orang pegawai peringkat pengurusan dan profesional bergred 41 dan 44 yang merupakan pelaksana dan peserta program PMI di JAKIM. Jadual 1 menunjukkan senarai informan yang terlibat dalam kajian ini.

Jadual 1: Senarai Informan Kajian

\begin{tabular}{|c|c|c|c|}
\hline $\begin{array}{c}\text { Bil. } \\
\text { Penemu bual }\end{array}$ & Jantina & Gred \& Jawatan & $\begin{array}{c}\text { Tempoh } \\
\text { Perkhidmatan }\end{array}$ \\
\hline TB1 & $\mathrm{L}$ & JUSA B & 32 tahun \\
\hline TB2 & $\mathrm{L}$ & $\begin{array}{c}\text { Timbalan Ketua Pengarah } \\
\text { M } 54 \\
\text { Pengarah Bahagian }\end{array}$ & 18 tahun \\
\hline TB3 & $\mathrm{L}$ & $\begin{array}{c}\text { S } 52 \\
\text { Ketua Penolong Pengarah Kanan }\end{array}$ & 23 tahun \\
\hline TB4 & $\mathrm{L}$ & $\begin{array}{c}\text { S } 52 \\
\text { Ketua Penolong Pengarah Kanan }\end{array}$ & 21 tahun \\
\hline TB5 & $\mathrm{L}$ & $\begin{array}{c}\text { S } 44 \\
\text { Penolong Pengarah Kanan }\end{array}$ & 15 tahun \\
\hline TB6 & $\mathrm{P}$ & $\begin{array}{c}\text { S } 44 \\
\text { Penolong Pengarah Kanan }\end{array}$ & 13 tahun \\
\hline TB7 & $\mathrm{L}$ & $\begin{array}{c}\text { S } 44 \\
\text { Penolong Pengarah Kanan }\end{array}$ & 12 tahun \\
\hline TB8 & $\mathrm{L}$ & $\begin{array}{c}\text { S } 41 \\
\text { Pegawai Hal Ehwal Islam }\end{array}$ & 10 tahun \\
\hline TB9 & $\mathrm{P}$ & $\begin{array}{c}\text { S } 41 \\
\text { Penolong Pengarah }\end{array}$ & 9 tahun \\
\hline TB10 & $\mathrm{P}$ & $\begin{array}{c}\text { S } 41 \\
\text { Penolong Pengarah }\end{array}$ & 9 tahun \\
\hline TB11 & $\mathrm{L}$ & $\begin{array}{c}\text { S } 41 \\
\text { Penolong Pengarah }\end{array}$ & 9 tahun \\
\hline TB12 & $\mathrm{L}$ & $\begin{array}{c}\text { S } 41 \\
\text { Penolong Pengarah }\end{array}$ & 9 tahun \\
\hline TB13 & $\mathrm{L}$ & $\begin{array}{c}\text { S } 41 \\
\text { Penolong Pengarah }\end{array}$ & 9 tahun \\
\hline TB14 & $\mathrm{L}$ & $\begin{array}{c}\text { S } 41 \\
\text { Penolong Pengarah }\end{array}$ & 7 tahun \\
\hline TB15 & $\mathrm{L}$ & Pegawai Hal Ehwal Islam & 6 tahun \\
\hline
\end{tabular}

Setelah selesai sesi temu bual, pengkaji telah telah menulis kandungan temu bual dalam bentuk transkripsi. Kemudian, hasil kandungan kesemua sesi temu bual telah dianalisis dengan menggunakan bantuan perisian ATLAS ti. Metod analisis data yang digunakan dalam kajian ini ialah metod analisis tema seperti yang dicadangkan oleh Braun dan Clarke (2006). Dalam kajian ini, kandungan transkripsi telah dianalisis dengan bantuan perisian ATLAS ti, iaitu dengan mencari isu-isu utama berkaitan dengan program-program pembangunan insan di JAKIM. Isu-isu ini disusun mengikut kod-kod tertentu yang kemudian dilabelkan mengikut kategori program-program yang dilaksanakan untuk menjayakan agenda pembangunan insan di JAKIM. 


\subsection{HASIL KAJIAN DAN PERBINCANGAN}

Hasil kajian melalui analisis data dengan menggunakan perisian ATLAS. ti menunjukkan terdapat lima program PMI yang dilaksanakan di JAKIM. Program tersebut ialah program berbentuk latihan, pendidikan dan ilmu pengetahuan, pengurusan sumber manusia, kualiti dan pengalaman kerja. Jadual 2 menunjukkan senarai tema, kod dan bilangan petikan program PMI di JAKIM. Sebanyak seratus dua puluh tujuh petikan mengenai program ini berjaya dikeluarkan melalui temu bual terhadap informan kajian.

Jadual 2: Senarai Tema, Kod dan Bilangan Petikan Program PMI di JAKIM

\begin{tabular}{clc}
\hline Tema & Kod & Bilangan Petikan \\
\hline Program-program PMI & Latihan & 32 \\
& Pendidikan dan Ilmu Pengetahuan & 32 \\
& Pengurusan Sumber Manusia & 26 \\
& Kualiti & 20 \\
& Pengalaman Kerja & 17 \\
Jumlah & & 127 \\
\hline
\end{tabular}

Sumber: ATLAS. ti

\subsection{Program Latihan}

Menurut Kwame dan Irene (2016), latihan yang diterima oleh pekerja merupakan komponen penting dalam menentukan kejayaan modal insan dan organisasi.

Hasil kajian melalui analisis data dengan menggunakan perisian ATLAS. ti menunjukkan program latihan merupakan program PMI utama di JAKIM. Sebanyak tiga puluh petikan mengenai program ini berjaya dikeluarkan melalui temu bual terhadap informan kajian. Terdapat dua sub tema bagi program latihan iaitu latihan jangka pendek dan panjang. Sub tema tersebut ditunjukkan dalam Jadual 3 seperti berikut:

Jadual 3: Program Latihan, Sub Tema dan Bilangan Petikan

\begin{tabular}{llc}
\hline Kod & Sub Tema & Bilangan Petikan \\
\hline Program latihan & Jangka pendek & 24 \\
& Jangka panjang & 6 \\
Jumlah & Pelan Operasi Latihan (POL) & 2 \\
& & 32 \\
\hline
\end{tabular}

Sumber: ATLAS. ti

Latihan jangka pendek merupakan program utama yang dilaksanakan oleh JAKIM. Sebahagian besar daripada informan berpandangan kebanyakan latihan yang dianjurkan oleh JAKIM adalah bersifat jangka masa pendek iaitu sebanyak dua puluh empat petikan telah dikeluarkan melalui temu bual. Beberapa informan menjelaskan program latihan jangka pendek sememangnya berjaya meningkatkan kecekapan mereka dan melahirkan modal insan yang berkualiti. Hasil kajian ini boleh dihubungkaitkan dengan penemuan oleh Philip (2010) iaitu pekerja berpandangan bahawa latihan semasa kerja dapat meningkatkan tahap kecekapan dan keterbukaan serta membekalkan mereka pengalaman bagi menjalankan tugas dengan sempurna. 
Salah seorang informan iaitu TB6 menyatakan latihan yang diadakan adalah bersifat khusus iaitu untuk bahagian-bahagian tertentu. Ini dinyatakan oleh beliau seperti berikut: "Kursus jangka pendek biasanya dianjurkan bersifat khusus untuk bahagian. Contoh bahagian hub halal, bahagian ini mengadakan program latihan khusus untuk mereka. Contohnya kursus pensijilan halal dan farmaseutikal halal. Bahagian penyelidikan pula menganjurkan kursus risikan”.

Selain daripada kursus dan latihan jangka pendek, JAKIM juga menganjurkan kursus latihan jangka masa panjang. Sebanyak enam petikan mengenai program ini dikeluarkan melalui temu bual informan kajian. Menurut beberapa informan, JAKIM menyediakan beberapa kursus yang telah diikuti oleh para pegawai JAKIM di luar negara. Sehubungan dengan ini, salah seorang informan iaitu TB3 berkata seperti berikut: "Kami pegawai JAKIM diberi peluang untuk berkursus ke luar negara. Contohnya kursus di Oxford University dan Muslim College London selama 3 hingga 6 bulan. Kita ada juga kursus-kursus di Darul Ifta Universiti Al-Azhar Mesir yang bertujuan untuk mendalami ilmu yang berkaitan dengan kefatwaan".

Salah seorang informan menyatakan terdapat juga kursus pegawai HEI JAKIM dihantar ke luar negara bagi menghadiri kursus risikan untuk meningkatkan kemahiran pegawai JAKIM dalam tugastugas risikan yang berkaitan dengan penyiasatan terhadap ajaran sesat dan pematuhan kepada undangundang Islam. Kemahiran risikan ini membantu pegawai JAKIM untuk bertindak lebih pantas semasa turun ke padang untuk menyiasat dan menangani hal-hal berkaitan dengan ajaran sesat dan perlanggaran undang-undang Islam.

Selain itu, pegawai JAKIM juga diberi peluang untuk membentangkan kertas kerja di dalam dan luar negara. Selain bertujuan untuk memberi pendedahan, peluang membentangkan kertas kerja mampu meningkatkan reputasi Malaysia sebagai pusat kewangan Islam dan hub halal.

Aspek terakhir dalam program latihan ialah Pelan Operasi Latihan (POL) seperti yang telah dijelaskan oleh dua orang informan yang merupakan pegawai atasan JAKIM. POL adalah satu kaedah yang digubal oleh JAKIM bagi memastikan pegawai pada gred 41 dan 44 menghadiri program latihan berkenaan kelapan-lapan bidang teras PHEI iaitu akidah dan aliran pemikiran, dakwah dan pembangunan insan, perundangan Islam, tarbiyyah dan tadribiyyah islamiah, kewangan dan ekonomi Islam, pengurusan halal, penyelidikan dan pembangunan dan pengurusan siasah syar'iyyah dengan hasrat menguasai sekurang-kurangnya empat bidang teras tersebut. Sehingga tahun 2015, POL ini telah berjaya dilaksanakan ke atas semua pegawai gred 41 dan 44 (Pelan Strategik JAKIM 2015-2019, 2015).

Pelbagai latihan yang telah dilaksanakan menunjukkan pihak pengurusan JAKIM meletakkan komitmen yang tinggi terhadap program PMI yang dilaksanakan. Hasil kajian ini menyokong cadangan Philip (2010) iaitu latihan merupakan satu pelaburan jangka panjang untuk mencapai objektif atau matlamat organisasi. Dengan adanya program-program latihan yang bagus, ia sebenarnya satu bentuk pelaburan. Melalui pelaburan tersebut, sudah pasti membantu JAKIM dalam usaha melahirkan modal insan berkualiti tinggi yang merupakan aset penting untuk menjayakan agenda transformasi organisasi.

\subsection{Program Pendidikan Dan Ilmu Pengetahuan}

Dengan menggunakan ATLAS. ti pengkaji telah mengenal pasti sebanyak dua puluh sembilan petikan melalui program berbentuk pendidikan dan ilmu pengetahuan. Manakala sebanyak dua sub

Page | 19 
tema bagi program ini iaitu i) peluang menyambung pengajian, dan ii) pencarian ilmu. Tema-tema tersebut ditunjukkan dalam Jadual 4 berikut:

Jadual 4: Program Pendidikan dan Ilmu Pengetahuan, Sub dan Bilangan Petikan

\begin{tabular}{clc}
\hline \multicolumn{1}{c}{ Kod } & \multicolumn{1}{c}{ Sub Tema } & $\begin{array}{c}\text { Bilangan } \\
\text { Petikan }\end{array}$ \\
\hline $\begin{array}{cl}\text { Program-program pendidikan dan } \\
\text { ilmu pengetahuan }\end{array}$ & \multicolumn{1}{c}{ Peluang menyambung pengajian } & 22 \\
& Pencarian ilmu & 7 \\
Jumlah & Pembinaan imej & 3 \\
\hline
\end{tabular}

Sumber: ATLAS. ti

Peluang menyambung pengajian merupakan program utama yang dilaksanakan di bawah program pendidikan. Sebanyak 22 petikan daripada informan telah diperoleh mengenai program tersebut. Kenyataan daripada para informan secara umumnya menjelaskan bahawa program-program ini sentiasa dijalankan sama ada di dalam atau luar negara bagi memastikan modal insannya mendapat pelbagai ilmu dan kepakaran yang diperlukan JAKIM. Program pendidikan sebenarnya membuka peluang kepada para pegawai PHEI menyambung pengajian ke peringkat Sarjana dan Doktor Falsafah bagi melahirkan modal insan yang pakar dalam sesuatu bidang. Ini seperti yang dinyatakan oleh informan TB1 seperti berikut: Pihak pengurusan di JAKIM memang memberi perhatian yang serius tentang isu pendidikan. Para pegawai diberi galakan untuk menyambung pengajian di peringkat Sarjana dan Doktor Falsafah untuk menjadikan mereka pakar dalam bidang-bidang khusus yang diperlukan di JAKIM".

Program pendidikan seperti kelas tafaquh fi din (kefahaman agama) juga merupakan program PMI yang sering kali diadakan di JAKIM di mana sebanyak tujuh petikan telah diperoleh daripada informan mengenai perkara tersebut. Program ini merupakan program berbentuk pengajian yang menggunakan kitab-kitab thurath dan kitab-kitab terkini. Hasil kajian ini boleh dihubungkaitkan dengan hasil kajian oleh Noor Shakirah dan Muhammad Azizan (2014) yang mendapati pendidikan berkaitan dengan Islam dan kerohanian merupakan latihan yang harus diberi penekanan bagi melahirkan modal insan yang berkualiti dan pakar dalam sesuatu bidang.

Seterusnya terdapat juga program pendidikan dan ilmu pengetahuan yang menekankan aspek pembinaan imej dan ketrampilan individu di JAKIM. Menurut seorang informan, imej yang bagus memainkan peranan penting dalam perkhidmatan PHEI. Oleh yang demikian proses pengambilan pegawai HEI turut mengambil kira aspek keterampilan individu. Informan tersebut juga menyatakan, melalui imej perkhidmatan PHEI akan dipercayai dan dipandang tinggi oleh masyarakat. Dalam hal ini, pengenalan dan perlaksanaan Diploma Pengurusan Islam (DPI) kepada pegawai HEI lantikan baru bermula pada tahun 2010 secara tidak langsung telah berjaya meningkatkan keyakinan, kemahiran dan keterampilan pegawai HEI di JAKIM di mata pelanggan dan pihak berkepentingan.

Kesimpulannya program pendidikan untuk membangunkan modal insan PHEI di JAKIM merangkumi dua program iaitu peluang menyambung pengajian dan pencarian ilmu. Dengan adanya program pendidikan yang mantap di JAKIM, ianya menyediakan barisan modal insan yang mempunyai pelbagai ilmu dan kemahiran untuk mendepani cabaran persekitaran dan membantu dalam mencapai objektif organisasi. Hasil kajian ini menyokong cadangan oleh Rahmah et al. (2011) iaitu program

Page | 20 
pembelajaran mesti disokong oleh organisasi agar modal insan mempunyai keupayaan untuk bertindak balas terhadap perubahan persekitaran dan konsisten dalam usaha mencapai matlamat organisasi.

\subsection{Program Pengurusan Sumber Manusia}

Program ketiga dalam program PMI di JAKIM ialah program pengurusan sumber manusia (PSM). Analisis daripada ATLAS. ti menunjukkan sebanyak dua puluh lapan petikan mengenai perkara ini berjaya dikeluarkan daripada informan kajian. Terdapat empat sub-tema berkenaan program ini iaitu pembangunan kerjaya, pusingan kerja, pelan penggantian dan pelan operasi latihan. Tema dan subtema tersebut ditunjukkan dalam Jadual 5 berikut:

Jadual 5: Program Pengurusan Sumber Manusia, Sub Tema dan dan Bilangan Petikan

\begin{tabular}{llc}
\hline \multicolumn{1}{c}{ Kod } & \multicolumn{1}{c}{ Sub Tema } & Bilangan Petikan \\
\hline Program Pengurusan Sumber & Pembangunan kerjaya & 15 \\
Manusia & Pusingan Kerja & 5 \\
& Pelan Penggantian & 6 \\
Jumlah & & 26 \\
\hline
\end{tabular}

Sumber: ATLAS. Ti

Jika dilihat melalui Jadual 5, pembangunan kerjaya menjadi aspek utama dalam program PSM di JAKIM. Buktinya sebanyak lima belas petikan mengenai perkara tersebut telah dikenal pasti melalui informan. Pembangunan kerjaya yang dimaksudkan meliputi aspek pemilihan pegawai baru dan kenaikan pangkat. Beberapa informan yang ditemu bual menjelaskan calon-calon yang berminat bekerja dengan JAKIM perlu melalui proses dan pemilihan yang ketat sebelum menerima pelantikan. Menurut para informan tersebut, mereka yang ingin memasuki perkhidmatan JAKIM perlu mengikuti 3 peringkat saringan iaitu peperiksaan, penilaian dan temuduga. Setelah calon lulus kesemua saringan tersebut, barulah dilantik sebagai seorang pegawai PHEI di JAKIM.

Selain aspek pemilihan, aspek yang diberi perhatian utama dalam pembangunan kerjaya di JAKIM ialah aspek kenaikan pangkat. Modul penilaian bagi kenaikan pangkat ke gred 48, 52 dan 54 di JAKIM memberi penekanan terhadap aspek kepimpinan dan, kebolehan menyampaikan idea dan visi. Aspek kedua dalam program PSM ini adalah pusingan kerja di mana sebanyak lima petikan dikeluarkan melalui empat informan. Para informan tersebut menerangkan pusingan kerja telah dilaksanakan terhadap pegawai PHEI di JAKIM apabila mereka telah berada di satu-satu unit atau jabatan selama lima atau enam tahun bagi memastikan pegawai PHEI itu menjadi lebih berdaya tahan, cekap dan memiliki pelbagai kemahiran.

Aspek ketiga dalam program PSM ini adalah pelan penggantian. Sebanyak enam petikan mengenai perkara ini dikeluarkan daripada empat informan. Menurut para informan tersebut, JAKIM mempunyai pelan penggantian bagi menyediakan pegawai-pegawainya yang berkualiti dan juga cekap untuk mengisi jawatan-jawatan di peringkat atasan JAKIM suatu masa nanti. Seperti kenyataan informan TB2: "Kita ada program komprehensif untuk pelan penggantian yang bermula dari pengambilan pegawai. Kita dah pastikan pegawai yang ada bakat kepimpinan, kita bangunkan potensinya untuk jadi pemimpin. Siapa yang tidak menunjukkan tokoh untuk jadi pemimpin, kita asuh dia jadi untuk Pakar Bidang (Subject Matter Expert)". 
Menurut Navarro et al (2015) apabila PSM sesebuah organisasi berada dalam keadaan baik, ianya akan membawa kepada peningkatan produktiviti dan pelbagai faedah lain. Program pembangunan manusia di JAKIM yang meliputi program pembangunan kerjaya, pusingan kerja, pelan penggantian dan POL sebenarnya mampu meningkatkan kecekapan kerja. Selain itu, ia juga membantu pekerja untuk membangunkan kerjaya masing-masing. Peluang pembangunan kerjaya yang disediakan akan menjadikan pekerja berasa gembira dan selamat untuk bekerja di JAKIM. Ini akan meningkatkan motivasi mereka untuk bekerja bersungguh-sungguh bagi menjayakan pelbagai agenda yang ditetapkan di JAKIM. Program latihan di bawah POL telah meningkatkan kemahiran komunikasi para pegawai JAKIM dan ini telah membantu mereka lebih beradab dalam program dakwah yang dijalankan. Selain itu, ia telah meningkatkan motivasi para pegawai JAKIM untuk lebih bergaul dengan pelbagai lapisan masyarakat.

\subsection{Program Kualiti}

Program keempat dalam program PMI di JAKIM ialah program kualiti. Analisis daripada perisian ATLAS. ti menunjukkan sebanyak dua puluh tiga petikan berjaya dikeluarkan mengenai perkara ini daripada informan kajian. Terdapat tiga sub tema bagi program kualiti di JAKIM iaitu inovasi, fokus kepada pelanggan dan pembinaan imej. Sub-sub tema tersebut ditunjukkan dalam Jadual 6 berikut:

Jadual 6: Program Kualiti, Sub Tema dan dan Bilangan Petikan

\begin{tabular}{lcc}
\hline Kod & Sub Tema & Bilangan Petikan \\
\hline Program Kualiti & Inovasi & 16 \\
& Fokus kepada Pelanggan & 4 \\
Jumlah & & 20 \\
\hline
\end{tabular}

Sumber: ATLAS. ti

Jadual 6 menunjukkan aspek inovasi merupakan sub tema utama bagi program kualiti di JAKIM dengan enam belas petikan daripada sebelas orang informan. Menurut salah seorang informan, para pegawai JAKIM diberi peluang seluas-luasnya untuk mengetengahkan idea berkaitan kualiti, kreativiti dan inovasi. Komitmen pihak pengurusan JAKIM terhadap kualiti dapat dilihat melalui perlaksanaan program sistem pengurusan kualiti ISO 9000 dan sistem pengurusan kualiti berteraskan syariah MS 1900 di Darul Quran, Kuala Kubu Baru, iaitu institusi pendidikan yang terletak di bawah pentadbiran JAKIM (Laman Web Darul Quran, 2016).

Salah seorang informan iaitu TB4 menyatakan program kualiti JAKIM dilaksanakan dengan panduan yang diberikan oleh MAMPU. Sehubungan dengan ini, beliau menegaskan seperti berikut: "Dalam program kualiti macam ikut apa yang diatur oleh MAMPU kerana JAKIM berada di bawah naungan JPM. MAMPU menekankan pengurusan yang kurang menggunakan kertas, maka pegawai di JAKIM perlu mahir dengan ICT. Selain itu, JAKIM menggunapakai Ekosistem Kondusif Sektor Awam (EKSA) untuk mewujudkan persekitaran yang bagus merangsang peningkatan kualiti kerja.

Pandangan beliau juga telah disokong oleh beberapa orang informan lain. Ini terbukti melalui penubuhan unit inovasi di JAKIM dalam memastikan program-program inovasi dapat dilaksanakan secara berterusan. Salah seorang informan telah memberikan satu contoh produk inovasi yang dilaksanakan JAKIM iaitu zakat pandu lalu (drive thru) yang telah dilaksanakan di Masjid Sultan Mizan, 
Putrajaya. Semua ini sebenarnya membuktikan JAKIM bersungguh-sungguh melakukan pelbagai program inovasi bagi memenuhi keperluan dan kehendak masyarakat Islam semasa.

Hasil kajian ini selari dengan hasil kajian oleh Ballout (2007), Samson dan Timothy (2014) iaitu organisasi yang menyediakan persekitaran kerja yang kondusif telah melahirkan pekerja iaitu modal insan yang produktif.

Program inovasi ternyata membawa kejayaan kepada JAKIM. Sebagai buktinya, JAKIM telah memenangi empat anugerah sempena Hari Inovasi dan Kecemerlangan (HIK) Jabatan Perdana Menteri (Laman Web JAKIM, 2015). JAKIM juga telah mendapat naib johan dalam Konvensyen Kumpulan Inovatif dan Kreatif (KIK) dan johan Anugerah Inovasi Jabatan Perdana Menteri kategori Halal Square dan Halal Inside (Perancangan eksekutif JAKIM, 2016).

Fokus kepada pelanggan merupakan aspek kedua dalam program kualiti di JAKIM. Terdapat empat petikan mengenai perkara ini diperolehi daripada informan. Beberapa informan yang ditemu bual mengatakan bahawa masyarakat atau pelanggan hari ini memerlukan jawapan segera dan spontan terhadap persoalan-persoalan agama yang dibangkitkan. Oleh itu, para pegawai JAKIM perlu memiliki ilmu yang tinggi dan mampu memberi jawapan yang pantas dan memuaskan terhadap isu-isu yang dikemukan oleh pelanggan. Sehubungan dengan ini, pihak pengurusan JAKIM telah menunjukkan komitmen dalam usaha membangunkan keupayaan dan ilmu para pegawainya seperti program pembangunan imam-imam masjid utama JAKIM dan juga program pembangunan Timbalan Mufti.

Selain itu, peningkatan kemahiran pegawai telah menyumbang secara langsung kepada kepada peningkatan kualiti perkhidmatan dan penambahbaikan pengurusan JAKIM. Ini sekaligus telah membantu JAKIM bergerak ke arah yang lebih positif dan memberangsangkan dalam aspek pengurusan organisasi. Hasil kajian ini boleh dihubungkaitkan dengan saranan oleh Zamri et al. (2016) iaitu pembinaan imej melalui penerapan budaya kerja cemerlang dalam pentadbiran supaya mampu mengelakkan sebarang kecuaian agar keyakinan masyarakat terhadap kerajaan sedia ada dapat ditingkatkan. Ini penting kerana menurut Zulfaqar (2017), pemerintah mempunyai tanggungjawab untuk mengurus segala hal berkaitan urusan sosial, politik dan ekonomi dalam negara berdasarkan kehendak syariah.

\subsection{Program Pengalaman Kerja}

Program kelima dalam program PMI di JAKIM ialah program berbentuk pengalaman kerja. Analisis daripada perisian ATLAS. ti menunjukkan sebanyak tujuh belas petikan mengenai perkara ini berjaya dikeluarkan daripada informan kajian. Terdapat 3 sub tema program pengalaman kerja seperti ditunjukkan dalam Jadual 7 berikut:

Jadual 7: Program Pengalaman Kerja, Sub Tema dan dan Bilangan Petikan

\begin{tabular}{llc}
\hline Kod & Sub Tema & Bilangan Petikan \\
\hline Program latihan & Penempatan & 8 \\
& Sangkutan & 6 \\
Jumlah & Perkongsian Bijak & 3 \\
& & 17 \\
\hline
\end{tabular}

Sumber: ATLAS. ti

Page | 23 
Jika dilihat melalui Jadual 7, didapati penempatan pegawai JAKIM menjadi agenda utama dalam program pengalaman kerja. Sebanyak lima petikan telah dikenal pasti melalui informan. Umpamanya seorang informan iaitu TB2 membangkitkan isu berkenaan dengan pusingan kerja bagi memastikan pengalaman dan kecekapan kerja seseorang pegawai di JAKIM: "Kita buat pusingan kerja bagi memastikan pegawai kita ada kompetensi yang cukup. Maknanya kalau pegawai itu dah lama berada di satu-satu bahagian, kita akan buat pertukaran kepada jawatan-jawatan lain untuk beri pendedahan baru kepada mereka".

Pandangan beliau turut disokong oleh beberapa orang informan lain yang menjelaskan pegawai JAKIM juga ditempatkan di kementerian-kementerian untuk mendapat pendedahan baru. Ini secara langsung telah meningkatkan kepakaran para pegawai terlibat. Hasil kajian ini boleh dikaitkan dengan hasil kajian oleh Mehralian et al. (2013) dan Lim et al. (2010) yang menunjukkan pertambahan pengalaman pekerja secara langsung telah meningkatkan kepakaran modal insan sesebuah organisasi.

Selain itu terdapat juga pegawai JAKIM melalui program sangkutan. Biasanya pegawai yang sudah lama berkhidmat di JAKIM akan di hantar ke tempat lain sama di sektor awam seperti di Suruhanjaya Perkhidmatan Awam (SPA) dan Majlis Keselamatan Negara (MKN). Sebahagian pegawai pula ditempatkan di luar negara bagi melahirkan pegawai yang lebih pakar dalam bidang mereka. Pandangan ini telah dinyatakan oleh seorang informan iaitu TB7 seperti berikut: "Selain itu, melalui program sangkutan, pegawai JAKIM diletakkan di institusi luar negara seperti di Akademik Fiqh Islam Sedunia untuk meningkatkan kepakaran beliau dalam bidang Fiqh”.

Aspek perkongsian bijak juga merupakan antara sub tema yang terdapat dalam program pengalaman kerja PMI di JAKIM. Biasanya JAKIM akan menghantar ramai pegawai-pegawai ke luar negara seperti di Mesir dan London untuk mendapat pendedahan dan pengalaman berkenaan dengan pentadbiran dalam persekitaran yang berbeza daripada persekitaran yang terdapat di JAKIM. Pengalaman di luar negara telah membantu dalam meningkatkan kecekapan para pegawai dalam aspek pentabiran, komunikasi dan kepimpinan. Apabila pegawai-pegawai tersebut kembali bertugas mereka akan berkongsi segala pengalaman ketika berada di luar negara dengan para pegawai JAKIM.

Hasil kajian ini menunjukkan pihak pengurusan JAKIM bijak membuat keputusan dalam melaksanakan program PMI iaitu pengalaman kerja meningkatkan kepakaran pegawai JAKIM seterusnya meningkatkan imej organisasi. Hasil kajian ini menyokong dapatan oleh Felicio et al. (2014) iaitu pengurus yang dapat meningkatkan kualiti perkhidmatan organisasi.

Hasil kajian mendapati lima program PMI dilaksanakan di JAKIM iaitu program latihan, program pengurusan sumber manusia, program pendidikan dan ilmu pengetahuan, program kualiti dan program pengalaman kerja. Program-program tersebut berjaya membangunkan modal insan dan meningkatkan kecekapan serta kemahiran pegawai JAKIM. Ini secara langsung telah membantu pegawai JAKIM lebih cekap dan pantas bertindak dalam menangani isu-isu yang berkaitan dengan ajaran sesat dan perlanggaran undang-undang Islam. Selain itu, kemahiran komunikasi para pegawai juga telah meningkat dan ini meningkatkan motivasi mereka untuk turun padang bergaul dengan masyarakat. Kemahiran komunikasi juga menjadikan para pegawai JAKIM lebih beradab dalam program-program dakwah yang dijalankan. Hasil kajian juga menunjukkan peningkatan kecekapan dan kemahiran para pegawai telah membantu dalam menambahbaik pengurusan organisasi JAKIM secara 
keseluruhannya. Penambahbaikan tersebut telah membawa perubahan positif, misalnya peningkatan imej organisasi JAKIM di kalangan pihak luar.

Program-program PMI telah berjaya dilaksanakan dengan lancar berdasarkan temu bual bersama informan seperti yang dibincangkan di atas. Pandangan oleh informan kajian mengenai program PMI di JAKIM boleh diringkaskan melalui Rajah 1:

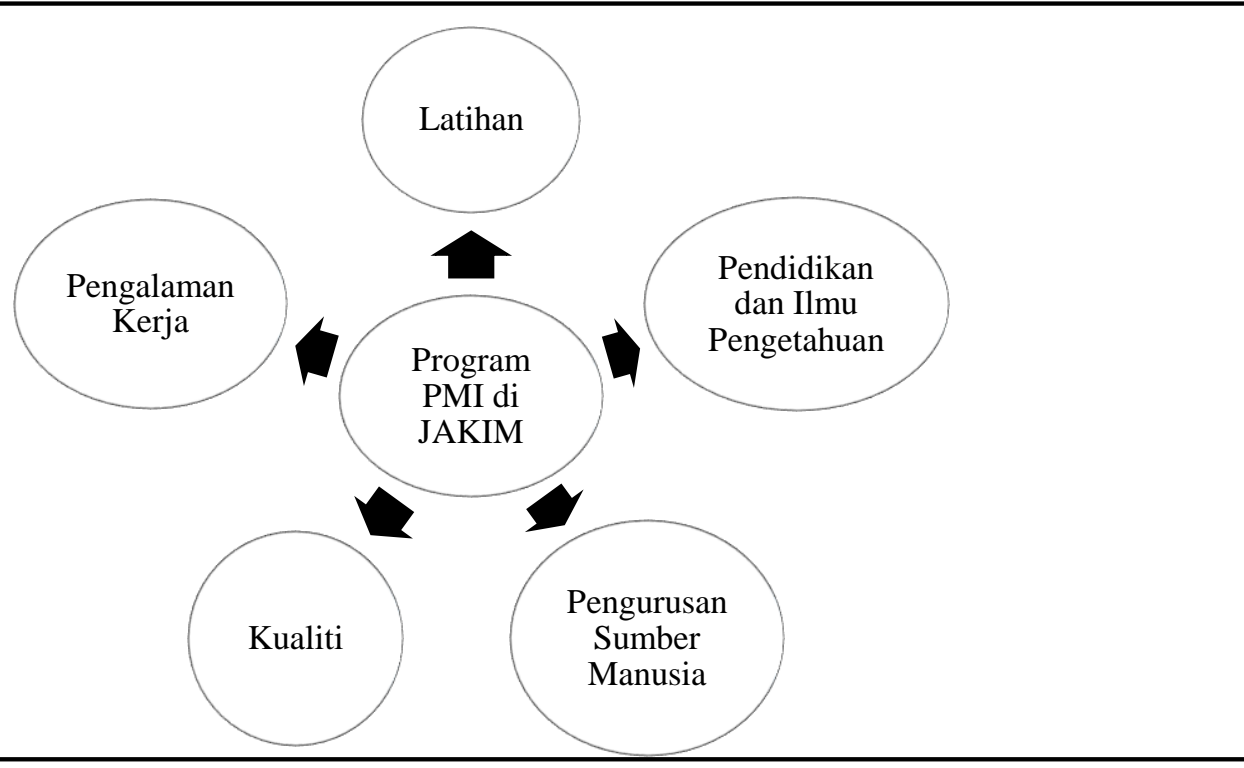

Rajah 1: Program Pengalaman Kerja, Sub Tema dan dan Bilangan Petikan

\subsection{KESIMPULAN}

Hasil kajian menunjukkan program PMI telah dilaksanakan dengan baik di JAKIM. Pelaksanaan program PMI berjaya menghasilkan modal insan yang cekap dan berkualiti bedasarkan kepada dapatan hasil kajian yang telah dihuraikan di atas. Dengan adanya modal insan yang cekap dan berkualiti, keupayaan organisasi JAKIM sebenarnya meningkat. Ini kerana pegawai-pegawai tersebut membantu dalam menjayakan agenda transformasi organisasi yang sedang dilaksanakan di JAKIM.

Dalam pada itu, program PMI di JAKIM tidak terlepas daripada cabaran tertentu. Dalam program latihan misalnya, terdapat para pegawai terutama pegawai yang telah lama berkhidmat kurang bermotivasi untuk menghadiri latihan-latihan yang disediakan. Ini kerana mereka merasakan sebahagian latihan-latihan tersebut mengandungi kandungan yang sama dan berulang. Oleh itu, pihak pengurusan JAKIM hendaklah memastikan program-program latihan mengandungi kandungan baru yang lebih bersifat terkini agar dapat menarik minat para pegawai. Selain itu, sebahagian pegawai JAKIM yang telah berjaya menamatkan pengajian peringkat sarjana dan doktor falsafah telah ditempatkan di bahagian atau unit yang tidak begitu bersesuaian dengan kepakaran mereka. Oleh itu, para pegawai tersebut tidak dapat menggunakan sepenuhnya kepakaran mereka dalam menjalankan tugasan. Dalam hal ini, pihak pengurusan JAKIM hendaklah melakukan semakan semula terhadap penempatan para pegawai tersebut agar mereka dapat menggunakan sepenuhnya kepakaran yang dimilikki untuk kebaikan organisasi.

Page | 25 
Hasil kajian ini memberi sumbangan terhadap pembangunan ilmu kerana telah mengisi kelompangan berkaitan dengan perlaksanaan program PMI institusi PHEI, khususnya di JAKIM. Kajian ini telah memberi gambaran yang jelas dan menyeluruh mengenai perlaksanaan modal insan dalam persekitaran institusi yang banyak menyediakan perkhidmatan kepada masyarakat Islam di Malaysia.

Hasil kajian ini boleh dijadikan panduan oleh para pentadbir di organisasi awam atau korporat di Malaysia dalam usaha mereka untuk menjayakan program PMI. Kajian ini dilaksanakan di JAKIM. Oleh itu, pengkaji akan datang boleh melanjutkan kajian ini di institusi pengurusan Islam yang lain di Malaysia seperti Jabatan Agama Islam Wilayah Persekutuan, Pusat Zakat Selangor dan Jabatan Kehakiman Syariah Malaysia. Kajian ini memfokuskan kepada program pembangunan modal insan. Maka kajian akan datang boleh memfokuskan kepada isu yang lain, seperti cabaran-cabaran dalam melaksanakan program modal insan.

\section{Rujukan}

Ab. Aziz Yusof. (2015). Penilaian Prestasi Dari Perspektif Islam. Dewan Bahasa dan Pustaka.

Abd Rahman Ahmad. (2006). Pembangunan Modal Insan, Apa dan Kenapa Perlu Dalam Konteks Organisasi di Malaysia. Kedah: Human Resources Academy. 21.

Abdifatah Ahmed Haji. (2016). Trend of Hidden Values and use of Intellectual Capital Information: Evidence from Malaysia. Accounting Research Journal, 29(1), 81-105.

Abdullah Md. Zin. (2011). Perubahan Sistem Pentadbiran Islam di Malaysia Sejak Merdeka, Kini dan Masa Hadapan. Prosiding Seminar Perubahan Sistem Pengurusan Islam di Malaysia. Penerbit Universiti Sains Islam Malaysia USIM, 1-32.

Adedeji, O., S. and Campbell, O., A. (2013). The Role of Higher Education in Human Capital Development in Nigeria. Available at SSRN: http://ssrn.com/abstract=2380878. Diakses pada 3 Januari 2017.

Adedipe, C.O. and Adeleke, B.O. (2016). Human Capital Development in the Nigerian Hospitality Industry. Worldwide Hospitality and Tourism Themes, 8(2), 195-206.

Adnan Non dan Nor 'Azzah Kamri. (2013). Pendekatan Pembangunan Modal Insan Menurut Perspektif Islam: Satu Sorotan Teoritis. Prosiding International Convention on Islamic Management. 27 \& 28 November 2013 Academy of Islamic Studies, University of Malaya, Kuala Lumpur.

Arabsheibani, G.R., Carneiro and F.C, Hanley, A. (2014). Human Capital and Earning Inequality in Brazil, 19881998: Quintile Regression Evidence. Worlds Bank Policy Research Working Paper. Available at http://econ.worldbank.org.

Ballout. H.I., (2007). Career Success The Effects Of Human Capital, Person-Environment Fit And Organizational Support. Journal of Managerial Psychology, 22(8), 741-765.

Becker, B.E. and Huselid, M.A., (2006). Strategic Human Resources Management: Where Do We Go From Here?. Journal of Management, 32(6), 898-925.

Becker, G. (1962). Investment in Human Capital: A Theoretical Analysis. The Journal of Political Economy, 70(5), 949.

Page | 26 
Biswajit Maitra. (2016). Investment in Human Capital and Economic Growth in Singapore. Global Business Review, $17(2), 425-437$.

Braun, V., and Clarke, V. (2006). Using Thematic Analysis in Psychology. Qualitative Research in Psychology, 3(2), 77-101.

Christopher Olusegun Adedipe and Bola Olusola Adeleke. (2016). Human Capital Development in The Nigerian Hospitality Industry. Worldwide Hospitality and Tourism Themes, 8(2), 195-206.

Cohen, L., Manion, L., and Morrison, K. (2013). Research Methods in Education. Routledge.

Colbert, B.A. (2004). The Complex Resource-based View: Implications For Theory and Practice In Strategic Human Resource Management. Academy of Management Review, 29(3), 341-358.

Cortés, E.C., Sáez, P.C.Z., Manchón, H.M. and García. M.U. (2015). Intellectual Capital in Family Firms: Human Capital Identification and Measurement. Journal of Intellectual Capital, 16(1), 199-223.

Daeboug, K. (2009). Human Capital and its Measurement. OECD World Forum.

Darul Quran (2016). Boleh didapati di http:/ /www.darulquran.gov.my/index.php?option=com_content\&view=article\&id=632\&Itemid=130.

Enrique Claver-Cortés, Patrocinio Carmen Zaragoza-Sáez, Hipólito Molina-Manchón and Mercedes ÚbedaGarcía. (2015). Intellectual Capital in Family Firms: Human Capital Identification and Measurement. Journal of Intellectual Capital, 16(1), 199-223.

Fatimah Nadirah Mohd Noor dan Nor Hayati Md Dahlal. (2015). Konsep Modal Insan Dalam Perlembagaan Itqanul Muluk Bi Takdil As-Suluk. Journal of Human Capital Development, 8(2), 101-114.

Felicio, J.A., Couto, E. and Caiado, J., (2014). Human Capital, Sosial Capital and Organizational Performance. Management Decision, 52(2), 350-364.

Gjalt De Jong. (2015). The Impact of Social and Human Capital on Individual Cooperative Behaviour. Critical Perspectives on International Business, 11(1), 4-29.

Guangqiang Liu, Lirang Pang, Dongmin Kong. (2017). Effects Of Human Capital On The Relationship Between Export And Firm Innovation. Chinese Management Studies, 11(2), 1-35.

Hairunnizam Wahid and Sanep Ahmad. (2014). Faktor Mempengaruhi Tahap Keyakinan Agihan Zakat. Jumal Ekonomi Malaysia, 48(2), 41 - 50.

Hong, Philip Young P. and Pandey, S. (2007). Human Capital as Structural Vulnerability of US Poverty. Equal Oportunities International, 26(1), 18-43.

J. Augusto, Eduardo Couto and Jorge Caiado. (2014). Human Capital, Sosial Capital and Organizational Performance. Management Decision, 52(2), 350-364.

Jabatan Kemajuan Islam Malaysia. (2009). Pelan Strategik JAKIM 2015 hingga 2019. Penerbit Jabatan Kemajuan Islam, Malaysia.

JAKIM (2015). Boleh didapati di http://www.islam.gov.my/berita-semasa/15-bahagian-dakwah/7-JAKIMrangkul-4-anugerah-hari-inovasi-dan-kecemerlangan-jpm. Diakses pada 15 Mei 2018.

Page $\mid 27$ 
JAKIM (2016). Boleh didapati di http://www.halal.gov.my/v4/index.php/my/arkib-berita/30-JAKIM-terimaanugerah-sme-sahabat-negara-award-2013. Diakses pada 15 Mei 2018.

JAKIM (2016). Boleh didapati di http://www.islam.gov.my/berita-semasa/14-bahagian-pembangunaninsan/384-sesi-penyerahan-surat-perakuan-memenuhi-keperluan-kualiti. Diakses pada 15 Mei 2018.

Kamal M. F. M., Affandi H. M., Hassan P. F., Ismail Z. and Mat M. C. (2017). A Comparative Study of Malaysian Public Project Management Training. Pertanika Journal Social Science and Humanities, 25 (S), 111 - 118.

Kaufman, B.E. and Miller, B.I. (2011). The Firm's Choice of HRM Practices: Economics Meets Strategic Human Resource Management. Industrial \& Labor Relations Review, 64(3), 526-557.

Khadijah Alavi, Rahim M. Sail, Lukman Abdul Mutalib, Anwar Ahmad, Shamsul Shah Tarjo and Nor Ellina Abdul Razak. (2013). Malaysian Graduates of Middle-Eastern Universities: Perspectives on Human Capital Development. Pertanika Journal Social Science and Humanities, 21, 79-92.

Khadijah Mohd Khambali @ Hambali, Nor Adina Binti Abdul Kadir, Khairul Anuar Bin Mohd Amin Khir. (2011). Relevensi Pemikiran Ibn Khaldun Terhadap Kemahiran Insaniah Dalam Pengurusan Pembangunan Modal Insan. Jurnal Usuludin, 34, 21-46. Universiti Malaya Press

Khalique, M., Bontis, N., Shaari, J.A.N. and Isa, A.H.B. (2015). Intellectual Capital in Small and Medium Enterprises in Pakistan. Journal of Intellectual Capital, 16(1), 224-238.

Kwame Adom and Irene Tiwaa Asare-Yeboa. (2016). An Evaluation of Human Capital Theory and Female Entrepreneurship in Sub-Sahara Africa. International Journal of Gender and Entrepreneurship, 8(4), 402-423.

Kwon, D. B. (2009). Human Capital and its Measurement. In Proc. The 3rd OECD World Forum on Statistics, Knowledge and Policy: 6-7.

Lai Wei Sieng and Ishak Yussof.(2014). Human Capital Accumulation and Economic Growth in Malaysia Investigating the Long Run Nexus. Jurnal Ekonomi Malaysia, 48(1), 155-165.

Laman Web JAKIM. (2018). http://www.islam.gov.my/berita-semasa/31-bahagian-penyelarasan-undangundang/135-sistem-penarafan-penguatkuasaan-dan-pendakwaan-syariah-jain-seluruh-malaysia. Diakses pada 14 Ogos 2018.

Laman Web JAKIM. (2018). Sistem Penarafan Penguatkusaan dan Pendakwaan Syariah JAIN seluruh Malaysia, dari internet: http://www.islam.gov.my/berita-semasa/31-bahagian-penyelarasan-undang-undang/135sistem-penarafan- penguatkuasaan-dan-pendakwaan-syariah-jain-seluruh-Malaysia. Diakses pada 14 Ogos 2018

Les, P. (2005). Optimizing Human Capital: Human Resource and People Management in Action. Emerald group publishing limited, 37(6), 299-303.

Lim, C.C.C., Chan, C.C.A. and Dallimore. P. (2010). Perceptions of Human Capital Measures: From Corporate Executives and Investors. Journal of Business Psychology, 25(4), 673-688.

Lokman Ab. Rahman, (2012). Penilaian Terhadap Pelaksanaan Persijilan Halal Jabatan Kemajuan Islam Malaysia (JAKIM). Tesis PhD, Akademi Pengajian Islam Universiti Malaya.

M. F. M. Kamal, H. M. Affandi, P. F. Hassan, Z. Ismail and M. C. Mat. (2017). A Comparative Study of Malaysian Public Project Management Training. Pertanika Journal Social Science \& Humanities, 25(S), 111-118. UPM Press

Page $\mid 28$ 
Mahmood Zuhdi Hj Abd. Majid. (2012). Persepsi Terhadap Pengurusan Hal Ehwal Islam di Malaysia: Harapan dan Kenyataan. Kertas pembentangan sempena Konvensyen Perkhidmatan Hal Ehwal Malaysia 2012 di Institut Latihan Islam Malaysia (ILIM), Bangi.

Md. Faruk Abdullah, (2012). The Role of Islam in Human Capital Development: A Juristic Analysis. Humanomics, 28(1), 64-75.

Mehralian, G., Akhavan, P., Hamid Reza Rasekh, H.R. and Ghatari, A.R. (2013). A Framework for Human Capital Indicators in Knowledge-Based Industries: Evidence From Pharmaceutical Industry. Measuring Business Excellence, 17(4), 88-101.

Michel Ferrary. (2015). Investing in Transferable Strategic Human Capital Through Alliances in the Luxury Hotel Industry. Journal of Knowledge Management, 19(5), 1007-1028.

Mohamed I.M., Mahazan, A.M., Adel M. A. and Mikail, I. (2017). Exploring the Role of Human Resource Management Practices on Labour Productivity in Libyan National Oil Corporations. Pertanika Journal Social Science and Humanities, 25 (1), 317 - 336.

Mohd Fauzi Hamat dan Mohd Khairul Naim Che Nordin. (2012). Tinjauan Kepentingan Pembangunan Modal Insan Di Malaysia. Jurnal Al-Tamaddun, 7(1), 75-89.

Mohd Kamal bin Hassan. (2013). Human Capital Management and Development in Light of the Contemporary Civilisational Crises, Ucaptama dalam International Convention on Islamic Management 2013. Anjuran Jabatan Syariah dan Pengurusan, APIUM dengan kerjasama YaPIEM pada 27 dan 28 Nov. 2013.

Muhamad Alihanafiah Norasid. (2011). Manhaj Rabbani oleh Sacid Hawwa terhadap Pembangunan Modal Insan: Satu Analisis. Jurnal Usuludin, 33, 91-114. Kuala Lumpur: Universiti Malaya Press.

Muhammad Hilmi Jalil dan Fakhrul Adabi Abdul Kadir. (2013). Kepentingan Kesihatan Diri Dalam Pembangunan Insan: Analisis Karya Falsafah Hamka. Jurnal Hadhari. 5(2), 69-84. JAKIM \& UKM Press.

Murwani, I. A. and Caesar, L. A. Y. (2016). Academic Achievement, Self-Efficacy, and Career Aspirations as the Predictors of Career Success for a First Job. Pertanika Journal Social Science and Humanities, 24 (S), 163 176.

Navarro, J.G.C., Carrion, G.C. and Wensley, A. (2015). Negative Aspects of Counter-knowledge on Absorptive Capacity and Human Capital. Journal of Intellectual Capital, 16(4), 763-778.

Nik Mutasim Nik Ab. Rahman, Nur Atiqah Abdullah, Khairul Akmaliah Adham dan Norazila Mat. (2014). Managerial Competencies: Comparing Conventional and Islamic Perspectives. Jurnal Pengurusan, 41, 91-99. Universiti Kebangsaan Malaysia (UKM)

Nor 'Azzah Kamri dan Nurul Izzah Mat Hassan. 2011. Perubahan Pentadbiran Islam Melalui Pembudayaan Nilai dan Etika Islam. Prosiding Seminar Perubahan Sistem Pengurusan Islam di Malaysia, Penerbit Universiti Sains Islam Malaysia USIM 2011: 33-50.

Pelan Strategik JAKIM 2009-2014. (2009). Terbitan Jabatan Kemajuan Islam Malaysia

Pelan Strategik JAKIM 2015-2019. (2015). Terbitan Jabatan Kemajuan Islam Malaysia.

Perancangan Eksekutif JAKIM (2016).Terbitan Jabatan Kemajuan Islam Malaysia

Page | 29 
Philip Law. (2010). Gaming Outcome of Accountants and Human Capital Theory: Macau Evidence. Management Research Review, 33 (12), 1174-1186.

Ployhart, R.E. and Moliterno, T.P. (2011). Emergence of the Human Capital Resource: A Multilevel Model. Academy of Management Review, 36(1), 127-150.

Prime Minister Office (PMO). (2013). Available at www.gov.my/modalinsan/index.html.

Rahmah Ismail, Ishak Yussof dan Mohd Nasir Mohd Saukani. (2011). Modal Insan dan Agihan Pendapatan di Malaysia. (Penerbit Universiti Kebangsaan Malaysia. Bangi).

Samson, A.J. and Timothy. G. (2014). Effects of Human Resource Training and Development on Productivity in the Nigerian Hospitality Industry. International Journal of Public Administration and Management Research, 2(2), 80-87.

Schultz, T.W., (1961). Investment in Human Capital. American Economic Review, 51(1), 1-17.

Schultz. (1961). Capital Formation by Education. Journal of Political Economy, 571-583.

Sedek Ariffin. (2012). Kaedah Menghafal al-Qur'an di Institusi Tahfiz al-Qur'an di Malaysia: Kajian Perbandingan di Antara Kaedah Darul Quran, JAKIM Dengan Kaedah al-Huffaz. Tesis Ph.D. Jabatan al-Quran dan alHadith. Akademi Pengajian Islam, Universiti Malaya.

Siti Arni Basir, Hasan Al-Banna Mohamed, Sharifah Hayaati Syed Ismail dan Ilhaamie Abdul Ghani Azmi. (2016). Model Integrasi Faktor Insaniah dalam Pelaksanaan ISO 9000: Analisis dari Perspektif Islam. Jurnal Usuluddin, 43, 137-170.

Siti Fatimah Abdullah, Maryati Mohd Yusof dan Dian Indrayani Jambari. (2016). Model Pengurusan Risiko Perancangan Sistem Maklumat di Sektor Awam. Jurnal Pengurusan, 48, 149-160. Universiti Kebangsaan Malaysia. 16 pages,. Galley Proof.

Siti Fatimah Ahmad dan Maimun Aqsha Lubis. (2015). Islam hadhari Dalam Pendidikan Pembangunan Modal Insan di Malaysia: Satu Analisa Epistimologi. Jumal Hadhari, 7 (1), 1-18. JAKIM \& UKM Press.

Siti Nur Aisya Sugumarie bt Abdullah dan Ahmad Zabidi b Abdul Razak . (2016). Hubungan Dasar Latihan Dalam Perkhidmatan Dengan Peningkatan Profesionalisme Guru-Guru Pendidikan Islam Sekolah Menengah Daerah Petaling Utama. Online journal of Islamic Education, 4(1), 17-27.

Sylwester, K. (2000). Income Inequality, Education Expenditures and Growth. Journal of Development Economic, 63, 379-398.

Trudi Wright. (2013). Information Culture in a Government Organization. Records Management Journal. 23(1), 1436.

Unger, J. M., Rauch, A., Frese, M., and Rosenbusch, N. (2011). Human Capital and Entrepreneurial Success: A Meta-Analytical Review. Journal of Business Venturing, 26, 341-358.

Utusan Malaysia. (2014). Jangan Salahkan JAKIM. Boleh didapati di http://ww1.utusan.com.my/utusan/Rencana/20140601/re_02/Jangan-salahkan JAKIM\#ixzz4MvrpSIBC. Diakses pada 15 Mei 2018.

Venhorst Viktor, Jouke Van Dijk and Wissen, L. V. (2010). Do The Best Graduates Leave The Peripheral Areas of The Netherlands?. Tijdscbrift Voor Economische En Sociale Geografie, 101(5), 521-537.

Page 30 
Wright, T. (2013). Information Culture in a Government Organization. Records Management Journal, 23(1), 14-36.

Yao Li-gen, Chen Juan. 2008. Study on the Evaluation of Core Competence of Corporation Based on the Human Capital. International Workshop on Modelling, Simulation and Optimization. The IEEE Computer Society, 65-68.

Zainudin Hashim, Fakhrul Adabi Abdul Kadir dan Yusmini Md. Yusoff. (2015). Pendekatan Hasan Al-Banna Dalam Pembangunan Insan Menerusi Majmu’at Al-Rasail. Jurnal Hadhari, 7(2), 49-62. JAKIM \& UKM Press.

Zamri bin Zainal Abidin, Rosli bin Mokhtar, Fakhri bin Sungit. (2016). Maqasid As-Syariah Dalam Indeks Syariah Malaysia, Muzakarah Fiqh \& International Fiqh Conference, 221-236.

Zula, Kenneth J. dan Thomas J. Chermack. (2007). Human Capital Planning: A Review of Literature and Implications for Human Resource Development. Human Resource Development Review, 6 (3), 245-262.

Zulfaqar Mamat. (2017). Indeks Syariah Malaysia. Jurnal Penyelidikan Islam, 27, 63-76. Penerbitan JAKIM. 